\title{
SPECTROPHOTOMETRIC METHOD FOR RANITIDINE DETERMINATION IN DRUGS USING RHODAMINE B
}

\author{
ZENOVIA MOLDOVAN \\ Department of Analytical Chemistry, Faculty of Chemistry, University of Bucharest, 92-96, Sos. Panduri, Bucharest-5, 050663, Romania \\ Hassan Y. Aboul-Enein ${ }^{I^{*}}$ \\ Pharmaceutical and Medicinal Chemistry Department, Pharmaceutical and Drug and Industries Research Division, National Research Centre, \\ Dokki, Cairo 12311, Egypt \\ (Received: March 1, 2012 - Accepted: August 8, 2012)
}

\begin{abstract}
A new spectrophotometric method has been developed for the determination of ranitidine hydrochloride (R.HCl) in bulk drug and in tablet formulation. The proposed method involves the addition of a measured excess of bromate-bromide reagent in hydrochloric acid medium to R.HCl, followed by determination of residual bromine by reacting with a fixed amount of Rhodamine B (RB) and measuring the absorbance at $\lambda_{\max }=557 \mathrm{~nm}$. Beer's law was found in the range of 0.3-3.2 $\mu \mathrm{g} \mathrm{ml}^{-1}$ of R.HCl, with a good correlation coefficient $(\mathrm{r}=0.9997)$. The limits of detection and quantification were calculated to be $0.08 \mu \mathrm{g} \mathrm{ml}{ }^{-1}$ and $0.24 \mu \mathrm{g}$ $\mathrm{ml}^{-1}$, respectively. The different experimental parameters affecting the development and stability of the proposed method were carefully studied and optimized. The validity of the proposed method tested by analyzing the pure and pharmaceutical formulations and compared well with those obtained by the official method, demonstrated good accuracy and precision.
\end{abstract}

Keywords: Spectrophotometry; Ranitidine hydrochloride; Rhodamine B; Redox reaction; Drug.

\section{INTRODUCTION}

Ranitidine, N-(2-\{[(5-dimethylamino)methyl $]-2$-furanyl $\}$ methylthioethyl)-N'-methyl-2-nitro-1,1'ethane diamine hydrochloride (abbreviated as $\mathrm{R} \cdot \mathrm{HCl}$ ), is a potent inhibitor of gastric acid secretion effective in the treatment and prophylaxis of gastrointestinal lesions aggravated by gastric acid secretion. In order to assure the quality of R.HCl containing pharmaceutical formulations, several methods have been developed for its determination, including high-performance liquid chromatography (HPLC) ${ }^{1-}$ ${ }^{6}$, high-performance thin-layer chromatography and scanning densitometry ${ }^{7}$, differential pulse polarography ${ }^{8}$, amperometry ${ }^{9}$, capillary electrophoresis ${ }^{10}$, conductometry $^{11}$, coulometry ${ }^{12}$, voltammetry ${ }^{13}$, potentiometry $^{14}$, fluorimetry ${ }^{15}$, chemiluminescence ${ }^{16}, \mathrm{AAS}^{17}$. The official method described in the United States Pharmacopeia ${ }^{18}$ is based on potentiometric titration of R.HCl with 0.1 mol $1^{-1} \mathrm{NaOH}$, requiring $300 \mathrm{mg}$ of drug for each titration. Although precise and exact, the procedure is time-consuming. HPLC procedures usually used for $\mathrm{R} \cdot \mathrm{HCl}$ determination need expensive and complex equipment, also consuming significant amounts of solvents. For these latter reasons, spectrophotometric methodologies, because of their inherent simplicity, low cost and wide availability were extensively proposed for R.HCl determination ${ }^{19-30}$. These methods are based on redox, coupling, charge-transfer complexation, and ion pair complexation reactions.

The present study describes a simple, rapid, cost-effective, precise, sensitive and accurate spectrophotometric method that is ideal for routine analysis of $\mathrm{R} \cdot \mathrm{HCl}$ in pharmaceuticals. The proposed spectrophotometric method involves treating a fixed amount of bromate-bromide solution in acid medium with $\mathrm{R} \cdot \mathrm{HCl}$ solution and determining the unreacted bromine by treating with a fixed amount of RB dye solution and measuring the absorbance at $\lambda_{\max }=557 \mathrm{~nm}$.

\section{EXPERIMENTAL}

\section{Reagents and materials}

Pharmaceutical grade ranitidine hydrochloride obtained from Biotend Chemikalien GmbH, Cologne, Germany) was used as received. Pharmaceutical products containing $\mathrm{R} \cdot \mathrm{HCl}$ were purchased from local commercial sources. Rhodamine B (RB), 9-(2-Carboxyphenyl)-3,6-bis(diethylamino)xanthenium chloride, was provided by Chemos GmbH-Germany. All solutions were prepared in bidistilled water. A stock standard solution containing $35 \mu \mathrm{g} \mathrm{ml}^{-1}$ $\mathrm{R} \cdot \mathrm{HCl}$ was prepared by dissolving $35 \mathrm{mg}$ of pure drug in water and diluted to the mark in $100 \mathrm{ml}$ calibrated flask. This solution was used for preparation of working standard solutions. A $6 \times 10^{-4} \mathrm{~mol} \mathrm{~L}^{-1}$ stock solution of RB was prepared by dissolving $28.7 \mathrm{mg}$ of dye (99\% purity) in water and diluting to $100 \mathrm{ml}$ in a calibrated flask. A bromate-bromide solution equivalent to $1000 \mu \mathrm{g}$ $\mathrm{ml}^{-1} \mathrm{NaBrO}_{3}$ and 10 -fold excess of $\mathrm{NaBr}$ was prepared by dissolving accurately weighed $100 \mathrm{mg}$ of $\mathrm{NaBrO}_{3}$ (Merck, Darrmstadt, Germany) and $1 \mathrm{~g}$ of $\mathrm{NaBr}$ (Merck, Darrmstadt, Germany) in water and diluting to the mark in a $100 \mathrm{ml}$ calibrated flask. This solution was diluted to obtain working concentration of $30 \mu \mathrm{g} \mathrm{ml}^{-1} \mathrm{NaBrO}_{3}$. An aqueous solution of hydrochloric acid $\left(5 \mathrm{~mol} \mathrm{l}^{-1}\right)$ was prepared by diluting $41.8 \mathrm{ml}$ of concentrated acid (Merck, Darmstadt, Germany, sp. gr. $1.18,37 \%$ ) to $100 \mathrm{ml}$ with water.

\section{Apparatus}

All absorbance measurements were made with a Jasco V-530 molecular absorption spectrometer provided with matched $1-\mathrm{cm}$ quartz cells.

Potentiometric measurements were carried out using an INOLAB 740 potentiometer (WTW GmbH, Weilheim,Germany). A glass electrode as the indicating electrode was used in conjunction with a double-junction saturated calomel electrode as reference electrode (WTW-GmbH).

\section{Recommended procedure for calibration graph}

In each of a series of $10 \mathrm{ml}$ calibrated flasks were placed $0.08-0.9 \mathrm{ml}$ of 35 $\mathrm{mg} \mathrm{ml}{ }^{-1} \mathrm{R} \cdot \mathrm{HCl}$ solution by means of a micro burette. To each of the nine flasks, $1 \mathrm{ml}$ of $5 \mathrm{~mol} \mathrm{l}^{-1} \mathrm{HCl}$ and $1 \mathrm{ml}$ bromate-bromide mixture $\left(30 \mu \mathrm{g} \mathrm{ml}^{-1}\right.$ in $\left.\mathrm{KBrO}_{3}\right)$ were added and the total volume was adjusted to $4 \mathrm{ml}$ by adding water. The flasks were stoppered and allowed to stand for $10 \mathrm{~min}$, with occasional shaking. Later, $0.5 \mathrm{ml}$ of $6 \times 10^{-4} \mathrm{~mol} \mathrm{~L}^{-1} \mathrm{RB}$ solution was added and the contents were diluted to volume with water and mixed well. The absorbance was measured at $557 \mathrm{~nm}$, after $10 \mathrm{~min}$, against water as reference. Blank experiments were also performed by adding bidistilled water instead of $\mathrm{R} \cdot \mathrm{HCl}$ solutions. The difference between the absorbance of samples in the presence and in the absence of $\mathrm{R} \cdot \mathrm{HCl}$ was taken into consideration.

\section{Precision and accuracy}

The accuracy and precision of the proposed method was established by determining the content of $\mathrm{R} \cdot \mathrm{HCl}$ in pure form at three different concentration levels $\left(0.70,1.75\right.$ and $\left.2.81 \mu \mathrm{g} \mathrm{ml}^{-1}\right)$. The intra day precision of the proposed method was performed by carrying out five independent analyses at each concentration level. The precision and accuracy of the spectrophotometric method were compared with those obtained by applying the reference method.

\section{Procedure for recovery tests}

The validity of the proposed method was presented by recovery studies using the standard addition method. For this purpose, known volumes $(0.1 ; 0.2$ and $0.3 \mathrm{~mL})$ of the stock standard solution of pure $\mathrm{R} \cdot \mathrm{HCl}(35 \mu \mathrm{g} \mathrm{mL}-1)$ were added to known volumes $(0.2 \mathrm{~mL}$, containing $10 \mu \mathrm{g} \mathrm{R} \cdot \mathrm{HCl})$ of the sample solution and the general procedure applied. Percent recovery of the added pure drug was calculated from: \%Recovery $\left.=\left[\left(\mathrm{A}_{1}-\mathrm{A}_{2}\right) / \mathrm{A}_{3}\right)\right] \times 100$ where $\mathrm{A}_{1}$ is the total amount of $\mathrm{R} \cdot \mathrm{HCl}$ found, $\mathrm{A}_{2}$ is the amount of $\mathrm{R} \cdot \mathrm{HCl}$ present in the formulation and found by the proposed method; $A_{3}$ is the amount of the pure 
$\mathrm{R} \cdot \mathrm{HCl}$ added to formulation and found by the proposed method.

\section{Analysis of R.HCl in pharmaceutical formulations}

The applicability of the proposed method for the determination of $\mathrm{R} \cdot \mathrm{HCl}$ has been tested on three brands of commercially available pharmaceutical formulations. For this purpose, five tablets of each pharmaceutical product were accurately weighed and ground into fine powder. An accurately weighed portion of the resulting powder, equivalent to $5 \mathrm{mg}$ of $\mathrm{R} \cdot \mathrm{HCl}$ was dissolved in water. Then it was filtered through a Whatman no. 42 filter paper directly into a $100 \mathrm{ml}$ standard volumetric flask. The residue was washed three times with water for complete recovery of the drug. The washings were added to the volumetric flask which was then filled to the mark with the same solvent, to obtain a solution of $50 \mu \mathrm{g} \mathrm{ml}^{-1} \mathrm{R} \cdot \mathrm{HCl}$. Aliquots of this solution $(0.2 \mathrm{ml})$, equivalent to $10 \mu \mathrm{g} \cdot \mathrm{HCl}$ were analyzed as described earlier.

\section{Procedure for recovery tests}

The validity of the proposed method was presented by recovery studies using the standard addition method. For this purpose, known amounts of pure $\mathrm{R} \cdot \mathrm{HCl}$ were spiked to its formulated preparation and the total amount of the drug was estimated by applying the proposed procedure.

\section{RESULTS AND DISCUSSION}

The proposed spectrophotometric method is indirect and is based on the determination of the residual bromine (insitu generated) after allowing the reaction between $\mathrm{R} \cdot \mathrm{HCl}$ and a measured amount of bromine to be complete. The surplus bromine was determined by reacting it with a fixed amount of Rhodamine-B dye. The method relies on the bleaching action of bromine on the dye, the decolouration being caused by the oxidative destruction of the dye. Various experimental parameters such as dye and bromine concentration, acidity and reaction time were optimized, and the optimum conditions were specified in the proposed procedure.

\section{Effect of dye concentration}

The first step in the assay procedure was the determination of the upper limit of the dye that could be determined spectrophotometrically. For this purpose, different volumes of $6 \times 10^{-4} \mathrm{~mol} \mathrm{l}^{-1} \mathrm{RB}$ solution were acidified with $1 \mathrm{ml}$ of 5 mol $1^{-1} \mathrm{HCl}$ and diluted to $10 \mathrm{ml}$ with water. The absorbance was measured at $557 \mathrm{~nm}$. The upper limit of RB that could be measured spectrophotometrically was found to be $3 \times 10^{-5} \mathrm{~mol} \mathrm{l}^{-1}$.

\section{Effect of bromate concentration on the oxidation of RB}

Preliminary experiments revealed that by adding bromate-bromide mixture in increasing concentrations of bromate, to a fixed concentration of $\mathrm{RB}$, the oxidation and thus the concomitant decrease in the absorbance of RB was observed (Fig. 1). A bromate concentration of $2 \times 10^{-5} \mathrm{~mol} \mathrm{l}^{-1}$ was found to irreversibly destroy the colour of $3 \times 10^{-5} \mathrm{~mol} \mathrm{l}^{-1} \mathrm{RB}$. The composition of the reaction product between $\mathrm{RB}$ and bromine, generated in situ, was established by adopting the limiting logarithmic method ${ }^{31}$. Two sets of experiments were carried out employing the general recommended procedures described above. The first set of experiments was carried out using increasing bromate concentrations $\left(8 \times 10^{-6}-2 \times 10^{-5} \mathrm{~mol} \mathrm{l}^{-1}\right)$ at fixed reagent concentration $\left(3 \times 10^{-5}\right.$ $\mathrm{mol} \mathrm{l^{-1 }} \mathrm{RB}$ in a total volume of $\left.10 \mathrm{ml}\right)$.

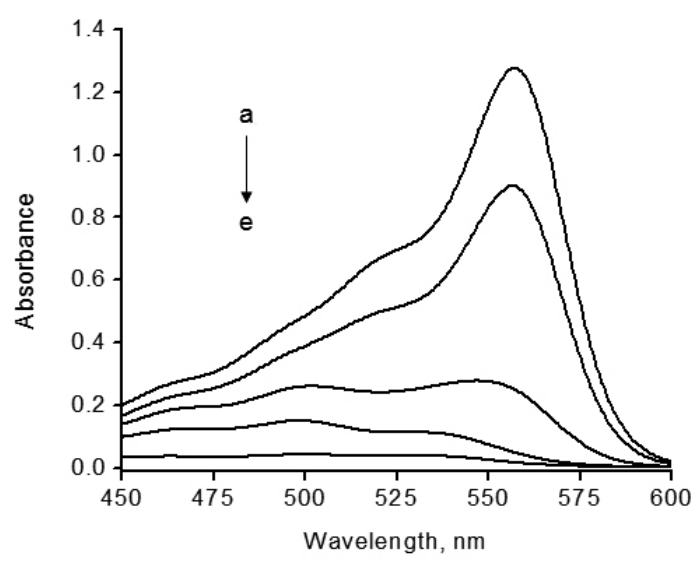

Fig. 1 - Absorption spectra of RB in the presence of bromate-bromide mixture.
Without oxidizing agent (a); with oxidizing agent, [Bromate], mol $^{-1}$ : (b) $0.5 \times 10^{-5}$; (c) $1 \times 10^{-5}$; (d) $1.5 \times 10^{-5}$; (e) $2 \times 10^{-5} ;[\mathrm{RB}]=3 \times 10^{-5} \mathrm{~mol} \mathrm{l}^{-1}$; $[\mathrm{HCl}]=0.5$ $\mathrm{mol} \mathrm{l}^{-1}$.
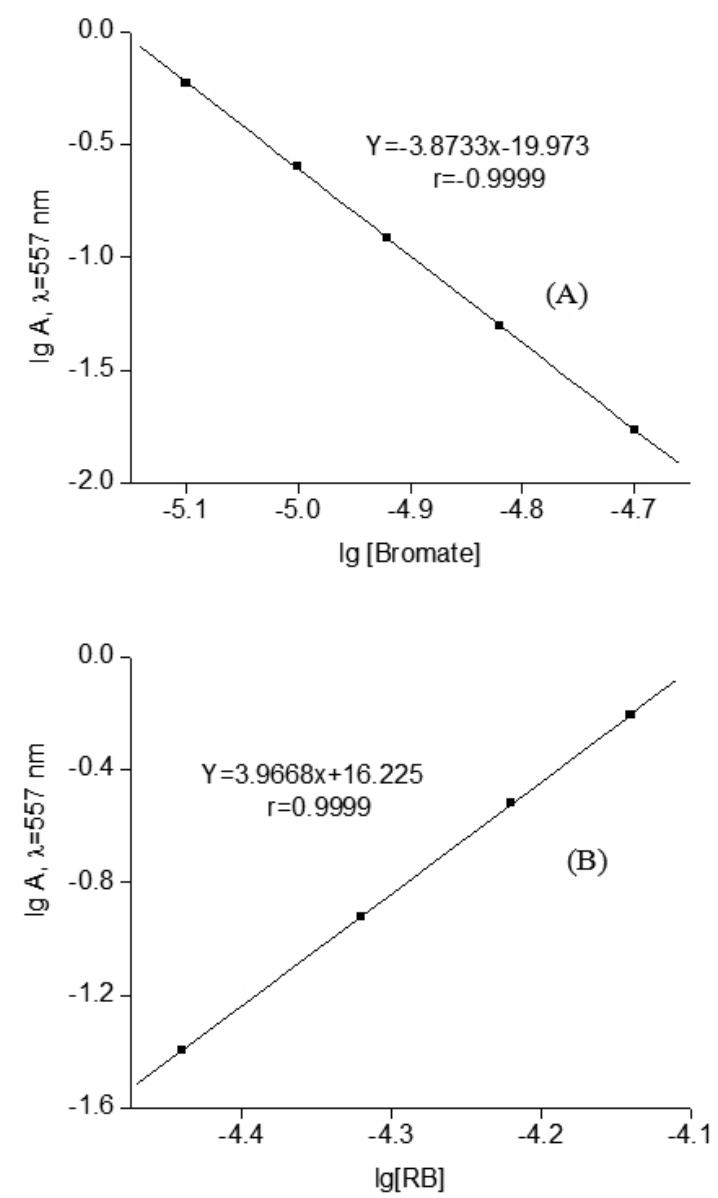

Fig. 2 - Limiting logarithmic plots to evaluate the stoichiometry of Bromate- $\mathrm{RB}$ reaction.

(A): variation of [Bromate]; (B): variation of [RB].

The second set of experiments were carried out using increasing RB concentrations $\left(4 \times 10^{-5}-7 \times 10^{-5} \mathrm{~mol}^{-1}\right)$ at fixed bromate concentration $\left(2 \times 10^{-5}\right.$ mol $1^{-1}$ ). The $\log$ absorbance values were plotted as a function of the $\log$ of the bromate concentration and RB concentration in the first and second sets of experiments, respectively (Fig. 2). The ratio of the slope of two straight lines was 0.98 . This means that the reaction proceeds in 1:1 (bromate:dye) stoichiometric ratio. Taking into account that one mole of bromate generates in situ, by the action on bromide and in acid medium, three moles of bromine (1):

$$
\mathrm{BrO}_{3}^{-}+5 \mathrm{Br}^{-}+6 \mathrm{H}^{+} \rightarrow 3 \mathrm{Br}_{2}+3 \mathrm{H}_{2} \mathrm{O}
$$

we assume that, in the experimental conditions, the bromination of RB takes place as is shown in Scheme 1.

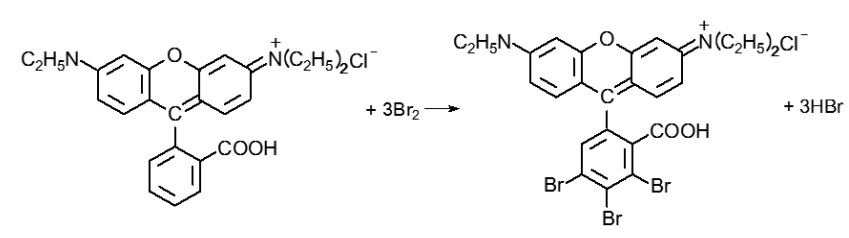

Scheme 1 - Reaction mechanism between RB and bromine

Effect of time on the oxidation of RB

The reaction time was determined by following the color decreasing 
of RB. After mixing the stoppered cell containing the reaction mixture, the absorbance was measured at 2 min intervals against a blank reagent. The absorbance measurement started at $30 \mathrm{~s}$ after adding the bromate solution. The absorbance-time profile of the RB-bromine reaction showed full color decreasing after $10 \mathrm{~min}$. Therefore, the reaction time of $10 \mathrm{~min}$ was chosen for color decreasing of RB.

\section{Effect of acid concentration on the oxidation of $\mathrm{R} \cdot \mathrm{HCl}$}

Hydrochloric acid was the medium of choice for the oxidation of $\mathrm{R} \cdot \mathrm{HCl}$ by bromine as well as its determination employing RB. The effect of $\mathrm{HCl}$ concentration on the $\mathrm{R} \cdot \mathrm{HCl}$ oxidation was studied from 0.83 to $2 \mathrm{~mol} \mathrm{l}^{-1}$ hydrochloric acid solution and $3 \times 10^{-5} \mathrm{~mol} \mathrm{l}^{-1} \mathrm{RB}$ solution. For this purpose, the recommended procedure was applied as follows: in each of a series of $10 \mathrm{ml}$ calibrated flasks were placed $0.5 \mathrm{ml}$ of $10^{-4} \mathrm{~mol}^{1^{-1}} \mathrm{R} \cdot \mathrm{HCl}$ solution by means of a micro burette. To each flask, $1 \mathrm{ml}$ bromate-bromide mixture $\left(30 \mu \mathrm{g} \mathrm{ml}^{-1}\right.$ in $\mathrm{KBrO}_{3}$, equivalent to $\left.2 \times 10^{-4} \mathrm{~mol}^{-1}\right), 1 \mathrm{ml}$ of $5 \mathrm{~mol} \mathrm{l}^{-1} \mathrm{HCl}$ and variable volumes of water $(0$ to $3.5 \mathrm{ml})$ were added to adjust the acidity in the range $0.83-2 \mathrm{~mol}$ $1^{-1}$. The flasks were stoppered and allowed to stand for $10 \mathrm{~min}$, with occasional shaking. Later, $0.5 \mathrm{ml}$ of $6 \times 10^{-4} \mathrm{~mol} \mathrm{l}^{-1} \mathrm{RB}$ solution was added and the contents was diluted to volume with water and mixed well.

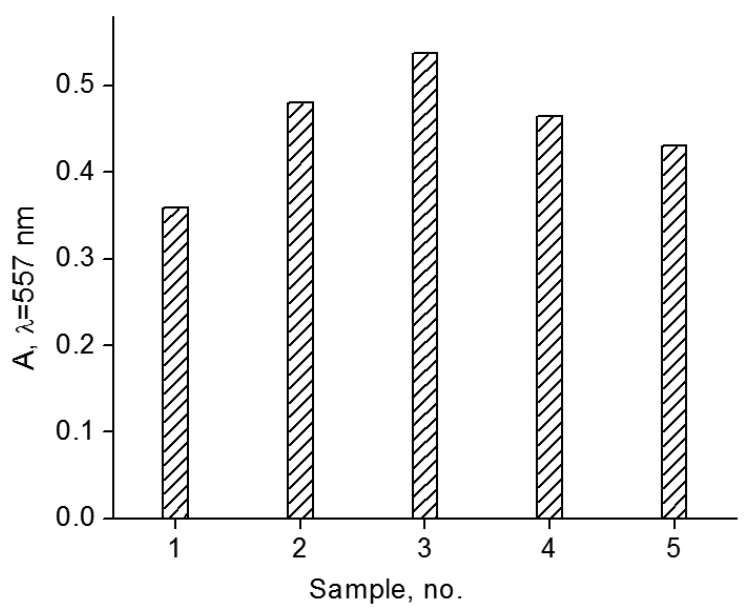

Fig. 3 - Effect of acid concentration on the oxidation of $\mathrm{R} \cdot \mathrm{HCl}$.

Acidity of the mixture $\mathrm{R} \cdot \mathrm{HCl}$ - Bromate, $\mathrm{mol} \mathrm{l}^{-1} \mathrm{HCl}$ : (1) 0.83 ; (2) $1 ;$ (3) 1.25 ; (4) 1.67 ; (5) 2 ; [Bromate $]=2 \times 10^{-5} \mathrm{~mol} \mathrm{l}^{-1} ;[\mathrm{RB}]=3 \times 10^{-5} \mathrm{~mol} \mathrm{l}^{-1}$.

As is shown in Figure 3, the analytical signal increased with increase of the $\mathrm{HCl}$ concentration up to $1.25 \mathrm{~mol} \mathrm{l}^{-1}$ and decreases for higher concentrations. Thus, the $1.25 \mathrm{~mol} \mathrm{l}^{-1} \mathrm{HCl}$ was selected for further work.

\section{Effect of time on the oxidation of $\mathrm{R} \cdot \mathrm{HCl}$}

According to the "Recommended procedure", two steps are required for samples preparation: in the first one, the mixture $\mathrm{R} \cdot \mathrm{HCl}$ - bromate bromide - $\mathrm{HCl}$ was set aside for a period $\left(\mathrm{t}_{1}\right)$; after oxidation of $\mathrm{R} \cdot \mathrm{HCl}$, in the second step, RB was added and the mixture was set aside $\left(\mathrm{t}_{2}\right)$ for oxidation reaction between $\mathrm{RB}$ and excess of bromine. The oxidation time of $\mathrm{R} \cdot \mathrm{HCl}$ by bromine was determined using the following conditions: by varying the time of $\mathrm{R} \cdot \mathrm{HCl}$-bromine reaction ( $\mathrm{t}_{1}=5-20 \mathrm{~min}$, at $5 \mathrm{~min}$ intervals), at a fixed time of RB-bromine reaction $\left(t_{2}=10 \mathrm{~min}\right)$. The absorbance time profile of $\mathrm{R} \cdot \mathrm{HCl}$ bromine-RB mixture showed maximum color increasing after $10 \mathrm{~min}$. Hence this reaction time of $\mathrm{R} \cdot \mathrm{HCl}$ with bromine was chosen for further experiments.

\section{Stoichiometry of the reaction between $\mathrm{R} \cdot \mathrm{HCl}$ and bromine}

Stoichiometry of the reaction between $\mathrm{R} \cdot \mathrm{HCl}$ and bromine was established by adopting the limiting logarithmic method ${ }^{31}$. Two sets of experiments were carried out employing the general recommended procedures described above. The first set of experiments was carried out using increasing bromate concentrations $\left(1.2 \times 10^{-5}-2 \times 10^{-5} \mathrm{~mol} \mathrm{l}^{-1}\right)$ at fixed $\mathrm{R} \cdot \mathrm{HCl}$ concentration $\left(5 \times 10^{-}\right.$ ${ }^{6} \mathrm{~mol} \mathrm{l}^{-1} \mathrm{R} \cdot \mathrm{HCl}$ in a total volume of $\left.10 \mathrm{ml}\right)$. The second set of experiments were carried out using increasing $\mathrm{R} \cdot \mathrm{HCl}$ concentrations $\left(2 \times 10^{-6}-6 \times 10^{-6} \mathrm{~mol}\right.$ $\left.1^{-1}\right)$ at fixed bromate concentration $\left(2 \times 10^{-5} \mathrm{~mol} \mathrm{l}^{-1}\right)$. The $\log$ absorbance values were plotted as a function of the $\log$ of the bromate concentration and $\mathrm{R} \cdot \mathrm{HCl}$ concentration in the first and second sets of experiments, respectively (Fig. 4). The ratio of the slope of two straight lines was 0.99 . This means that the reaction proceeds in 1:1 (bromate: $\mathrm{R} \cdot \mathrm{HCl}$ ) stoichiometric ratio. According to literature data ${ }^{25}$, this behavior confirms that three moles of bromine, generated in situ by the action of bromate-bromide mixture (see equation (1)), reacts with one mole of $\mathrm{R} \cdot \mathrm{HCl}$ as shown in Scheme 2.
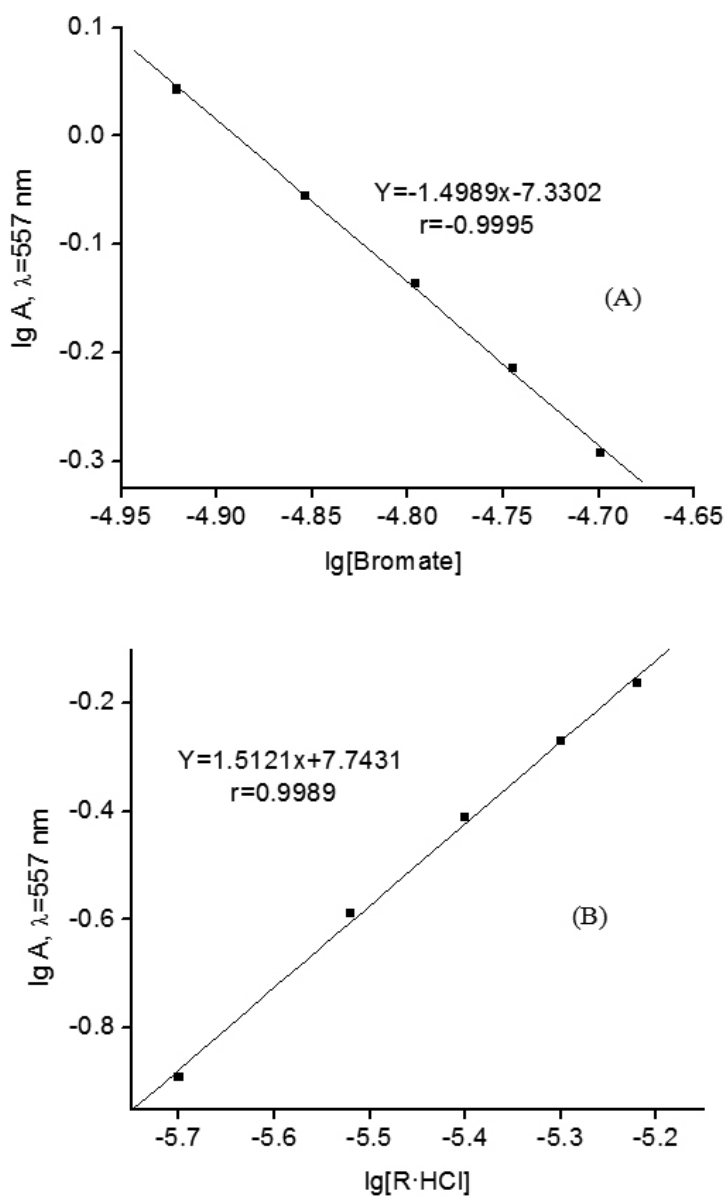

Fig. 4 - Limiting logarithmic plots to evaluate the stoichiometry of Bromate- $\mathrm{RB}$ reaction.

(A): variation of [Bromate]; (B): variation of [R $\cdot \mathrm{HCl}]$.

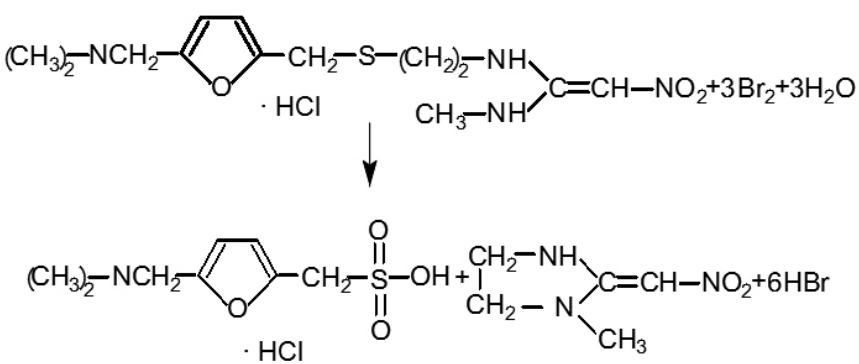

Scheme 2 - Reaction mechanism between $\mathrm{R} \cdot \mathrm{HCl}$ and bromine

\section{Analytical Parameters}

Analytical characteristics obtained under the optimum experimental conditions are shown in Table 1. Limit of detection (LOD) and limit of quantification (LOQ) were calculated as follows $\mathrm{s}^{32}$ : LOD $=3.3 \mathrm{~s} / \mathrm{b}$; LOQ $=10 \mathrm{~s} / \mathrm{b}$, where $\mathrm{b}$ is the slope and $\mathrm{s}$ is the standard deviation of the regression line. In order to apply these formulas, firstly, it was represented the calibration graph, in the concentration range $0.3-3.2 \mu \mathrm{g} \mathrm{ml} l^{-1} \mathrm{R} \cdot \mathrm{HCl}$, by using the program Origin. Thus, it was plotted the $\mathrm{x}_{\mathrm{i}} \mathrm{y}_{\mathrm{i}}$ points (corresponding to the nine standard solutions) on a $\mathrm{xy}$ graph (where $\mathrm{x}=$ concentration of the standard solution

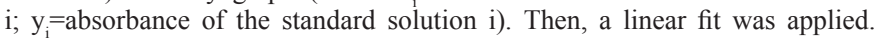


Automatically, the calibration line and its parameters appeared on the Origin file. These parameters are:

- Linear regression equation $\left(A=0.3815 \times[R \cdot H C l]^{\mathrm{a}}-0.127\right)$

- Correlation coefficient, r (0.9997)

- Standard deviation of the regression line, $\mathrm{s}_{\mathrm{o}}(0.009)$.

These parameters are shown in Table 1.

A comparison between the proposed method and other reported methods is shown in Table 2. As shown in this table, some of the reported procedures ${ }^{20,27}$ have higher detection limits. Moreover, some of the reported methods are alike or more sensitive but have drawbacks such as having a narrow linear dynamic range $^{26}$, involving extraction ${ }^{19,21}$ or being performed at high temperatures ${ }^{22,23,26}$.
Table 1 - Analytical data for the regression equation of the proposed method.

\begin{tabular}{|l|l|}
\hline Parameter & Value \\
\hline$\lambda_{\max }, \mathrm{nm}$ & 557 \\
${\text { Linear range, } \mu \mathrm{g} \mathrm{ml}^{-1}}_{\text {Correlation coefficient, } \mathrm{r}}$ & $0.3-3.2$ \\
Linear regression equation & 0.9997 \\
Slope & $\mathrm{A}=0.3815 \times[\mathrm{R} \cdot \mathrm{HCl}]^{\mathrm{a}}-0.127$ \\
Standard deviation of the regression line, $\mathrm{s}_{\mathrm{o}}$ & 0.3815 \\
$\mathrm{LOD}, \mu \mathrm{g} \mathrm{ml}^{-1}$ & 0.009 \\
$\mathrm{LOQ}, \mu \mathrm{g} \mathrm{ml}^{-1}$ & 0.08 \\
\hline
\end{tabular}

${ }^{\mathrm{a}}$ Concentration of $\mathrm{R} \cdot \mathrm{HCl}\left(\mu \mathrm{g} \mathrm{ml}^{-1}\right)$.

Table 2 - Comparison of the proposed method with existing spectrophotometeric methods for the determination of ranitidine.

\begin{tabular}{|c|c|c|c|c|c|}
\hline Reagents & $\begin{array}{l}\text { Linear range, } \\
\qquad \mu \mathrm{g} \mathrm{ml}^{-1}\end{array}$ & $\begin{array}{l}\text { LOD } \\
\mu \mathrm{g} \mathrm{ml}^{-1}\end{array}$ & $\begin{array}{c}\mathrm{LOQ} \\
\mu \mathrm{g} \mathrm{ml}^{-1}\end{array}$ & Ref. & Remarks \\
\hline Bromothymol blue & $1-20$ & - & - & 19 & $\begin{array}{l}\text { Involves extraction and } \\
\text { strict } \mathrm{pH} \text { control }\end{array}$ \\
\hline Nitrite- $\mathrm{Cu}^{2+} / \mathrm{Br}^{-}$ & $300-12000$ & 100 & - & 20 & $\begin{array}{l}\text { Involves flow injection } \\
\text { automated assembly, least } \\
\text { sensitive }\end{array}$ \\
\hline $\mathrm{KMnO}_{4} / \mathrm{N}$-bromosuccinimide-azine dyes & $5-30$ & - & - & 21 & $\begin{array}{l}\text { Involves extraction and } \\
\text { uses unstable } \\
\text { reagent }\end{array}$ \\
\hline 7-chloro-4-nitrobenz-2-oxa-1,3-diazole & $2-20$ & 0.13 & - & 22 & $\begin{array}{l}\text { Requires thermostating at } \\
60^{\circ} \mathrm{C} \text { for } 25 \mathrm{~min}\end{array}$ \\
\hline Tetracyanoquinodimethane & $1-6$ & - & - & 23 & $\begin{array}{l}\text { Requires thermostating at } \\
70^{\circ} \mathrm{C} \text { for } 10 \text { min and it is } \\
\text { less sensitive }\end{array}$ \\
\hline $\mathrm{Ce}(\mathrm{IV})$-chromotrope $2 \mathrm{R}$ & $0.1-2.8$ & 0.03 & 0.07 & \multirow{2}{*}{26} & \multirow{2}{*}{$\begin{array}{l}\text { Narrow range of linear } \\
\text { response. Involve boiling } \\
\text { for } 5 \text { min and has narrow } \\
\text { range of linear response }\end{array}$} \\
\hline $\mathrm{Ce}(\mathrm{IV})$-rhodamine $6 \mathrm{G}$ & $0.1-2.6$ & 0.03 & 0.06 & & \\
\hline Dichromate-diphenylcarbazide & $5-50$ & 0.83 & 2.52 & \multirow{3}{*}{27} & \multirow{3}{*}{ Less sensitive } \\
\hline Dichromate-iron(II)-thiocyanate & $5-80$ & 1.59 & 4.83 & & \\
\hline Dichromate-iron(II)-orthophenanthroline & $10-100$ & 3.07 & 9.28 & & \\
\hline Rhodamine B-bromate-bromide & $0.3-3.2$ & 0.08 & 0.24 & $\begin{array}{c}\text { Present } \\
\text { work }\end{array}$ & Simple and sensitive \\
\hline
\end{tabular}

\section{Accuracy and precision}

To determine the accuracy and precision of the method, pure $\mathrm{R} \cdot \mathrm{HCl}$ solutions containing three different concentrations within the linearity range were analysed in five replicates. The results obtained from this investigation are summarised in Table 3 . The relative standard deviation $(\leq 1.26 \%)$ and the percent recovery from $99.67 \%$ to $100.36 \%$ can be considered to be satisfactory. Table 3 - Precision and accuracy of the proposed method.

\begin{tabular}{|c|c|c|c|c|}
\hline \multicolumn{2}{|c|}{$\mathrm{R} \cdot \mathrm{HCl}, \mu \mathrm{g} \mathrm{ml}^{-1}$} & \multirow{2}{*}{$\mathrm{S}, \mu \mathrm{g} \mathrm{ml}^{-1}$} & \multirow{2}{*}{$\mathrm{RSD}, \%$} & $\mathrm{R}, \%$ \\
\cline { 1 - 2 } Taken & ${ }^{\mathrm{a}}$ Found $\pm t S / N^{-0.5}$ & & 1.06 & 99.67 \\
\hline 0.70 & $0.70 \pm 0.01$ & 0.01 & 1.26 & 100.36 \\
\hline 1.75 & $1.76 \pm 0.03$ & 0.02 & 0.78 & 99.70 \\
\hline 2.81 & $2.80 \pm 0.01$ & 0.03 & \\
\hline
\end{tabular}

${ }^{\mathrm{a}}$ Mean $\pm 95 \%$ confidence limit, for $\mathrm{N}=5 ; \mathrm{t}=2.77=\mathrm{t}$-distribution for confidence level of $95 \%$ with $\mathrm{N}-1$ degrees of freedom $\mathrm{S}=$ Standard deviation; $\mathrm{RSD}=$ Relative standard deviation; $\mathrm{R}(\%)=$ percent recovery.

\section{Recovery study}

The accuracy and validity of the proposed methods were further ascertained by performing recovery studies. The purpose of the recovery tests was also to verify the accuracy of the proposed method, applied on real samples. Pre-analysed tablet powder was spiked with pure $\mathrm{R} \cdot \mathrm{HCl}$ at three different levels and the total was found by the proposed methods. Each determination was repeated three times. The results were reproducible with low standard deviation and the mean recovery ranged from $99.44-100.65 \%$ (Table 4). Hence, the recovery of the pure drug added was quantitative and revealed that co-formulated substances such as which are commonly presented in pharmaceutical formulations such as talc, starch, gelatin, magnesium stearate, calcium gluconate and calcium dihydrogen orthophosphate, did not interfere with the determination.

\section{Statistical analysis of the results}

The performance of the proposed method was judged further by the Student's t-test for accuracy and F-test for precision. At the 95\% confidence level, the calculated t- and F-values did not exceed the tabulated values $(\mathrm{t}=2.18$ and $\mathrm{F}=3.63)$, indicating that there is a close agreement between the results obtained by the proposed and official methods. Thus, statistical analysis of the results ${ }^{33}$, obtained by the official ${ }^{18}$ and the proposed method using Student's t-test and variance ratio F-test, show no significant difference between the performance of the two methods regarding the accuracy and precision, respectively (Table 5). 
Table 4 - Results of recovery study using standard-addition method.

\begin{tabular}{|c|c|c|c|c|c|}
\hline \multirow{2}{*}{ Tablet brand name ${ }^{a}$} & \multirow{2}{*}{$\begin{array}{l}\text { Amount of } \\
\text { pure } \mathrm{R} \cdot \mathrm{HCl} \text { in } \\
\text { tablet, } \mu \mathrm{g}\end{array}$} & \multicolumn{2}{|c|}{ Amount of pure $\mathrm{R} \cdot \mathrm{HCl}, \mu \mathrm{g}$} & \multirow{2}{*}{$\begin{array}{l}\text { Amount of pure } \mathrm{R} \cdot \mathrm{HCl} \\
\text { added } \pm \mathrm{S}^{\mathrm{b}}, \mu \mathrm{g}\end{array}$} & \multirow{2}{*}{$\begin{array}{c}\text { Recovery of } \mathrm{R} \cdot \mathrm{HCl} \\
\text { added, } \\
\%\end{array}$} \\
\hline & & added & found & & \\
\hline \multirow{4}{*}{$\begin{array}{l}\text { Ranitidina LPH } \\
150 \mathrm{mg}\end{array}$} & 10 & - & 9.54 & - & - \\
\hline & 10 & 3.5 & 13.07 & $3.53 \pm 0.2$ & 100.50 \\
\hline & 10 & 7.0 & 16.60 & $7.06 \pm 0.13$ & 100.65 \\
\hline & 10 & 10.5 & 19.98 & $10.44 \pm 0.31$ & 99.44 \\
\hline \multirow{4}{*}{$\begin{array}{l}\text { Ulcoran } \\
150 \mathrm{mg}\end{array}$} & 10 & - & 9.61 & - & - \\
\hline & 10 & 3.5 & 13.14 & $3.53 \pm 0.27$ & 100.62 \\
\hline & 10 & 7.0 & 16.60 & $6.99 \pm 0.13$ & 99.65 \\
\hline & 10 & 10.5 & 20.14 & $10.53 \pm 0.25$ & 100.33 \\
\hline \multirow{4}{*}{$\begin{array}{l}\text { Zantac } \\
150 \mathrm{mg}\end{array}$} & 10 & - & 9.75 & - & - \\
\hline & 10 & 3.5 & 13.27 & $3.52 \pm 0.24$ & 100.40 \\
\hline & 10 & 7.0 & 16.76 & $7.01 \pm 0.15$ & 99.78 \\
\hline & 10 & 10.5 & 20.14 & $10.39 \pm 0.19$ & 100.30 \\
\hline \multicolumn{6}{|c|}{$\begin{array}{l}\text { aRanitidina LPH - LABORMED PHARMA Romania; Ulcoran - EUROPHARM Romania; Z Zantac - GLAXO WELLCOME SA - } \\
\text { Spain } \\
\text { 'Mean of three measurements } \pm \text { standard deviation (S). }\end{array}$} \\
\hline
\end{tabular}

Table 5 - Application of the proposed method and official methods for the determination of R $\cdot H C$ in pure pure form.

\begin{tabular}{|c|c|c|}
\hline Parameters & & \\
\hline $\begin{array}{l}\text { No. of experiments } \\
\text { Mean found }{ }^{\mathrm{a}} \pm \mathrm{SD}, \% \\
\text { RSD, \% } \\
\text { Variance } \\
\text { Student's t-value }{ }^{\mathrm{b}} \\
\text { F-test value }^{\mathrm{b}}\end{array}$ & $\begin{array}{l}5 \\
99.70 \pm 0.78 \\
0.78 \\
0.61 \\
0.56(2.18) \\
1.14(3.63)\end{array}$ & $\begin{array}{l}10 \\
99.93 \pm 0.73 \\
0.73 \\
0.53 \\
- \\
-\end{array}$ \\
\hline \multicolumn{3}{|c|}{$\begin{array}{l}\text { a Results obtained at a concentration level of } 2.81 \mu \mathrm{g} \mathrm{ml}^{-1} \mathrm{R} \cdot \mathrm{HCl} \text { (see } \\
\text { Table 3). } \\
\text { b Values in parantheses are the tabulated values of } \mathrm{t} \text { and } \mathrm{F} \text { respectively at } \\
\text { confidence level } \mathrm{P}=95 \% \text {. }\end{array}$} \\
\hline
\end{tabular}

\section{Application}

The proposed method was applied to the determination of $\mathrm{R} \cdot \mathrm{HCl}$ in three brands of tablets. The results obtained by the proposed method were compared statistically with that of the reference method ${ }^{18}$. There is a close agreement between the results obtained by the proposed method and by the official method regarding accuracy (according to t-test) and precision (according to F-test) as shown in Table 6.

Table 6 - Determination of $\mathrm{R} \cdot \mathrm{HCl}$ content in pharmaceutical tablets using the proposed and the official methods.

\begin{tabular}{|c|c|c|c|c|}
\hline \multirow{2}{*}{ Drug formulation } & \multicolumn{2}{|c|}{$\mathrm{R} \cdot \mathrm{HCl}$ Found $\mathrm{a}^{\mathrm{a}}, \% \pm \mathrm{SD}$} & \multirow{2}{*}{$\mathrm{t}-$ Value $^{\mathrm{b}}$} & \multirow{2}{*}{ F-Value } \\
\hline & Proposed method & Official method $^{18}$ & & \\
\hline $\begin{array}{c}\text { Ranitidina LPH, } \\
150 \mathrm{mg} \mathrm{R} \cdot \mathrm{HCl} / \text { tablet }\end{array}$ & $98.25 \pm 0.82$ & $99.57 \pm 1.02$ & 2.22 & 1.64 \\
\hline $\begin{array}{c}\text { Ulcoran, } \\
150 \mathrm{mg} \mathrm{R} \cdot \mathrm{HCl} / \text { tablet }\end{array}$ & $98.95 \pm 1.36$ & $99.68 \pm 0.75$ & 1.05 & 3.29 \\
\hline $\begin{array}{c}\text { Zantac, } \\
150 \mathrm{mg} \mathrm{R} \cdot \mathrm{HCl} / \text { tablet }\end{array}$ & $101.36 \pm 1.05$ & $100.68 \pm 0.94$ & 1.08 & 1.25 \\
\hline
\end{tabular}

\section{CONCLUSIONS}

The proposed method is more sensitive than other reported methods, permiting the determination of a concentration down to $0.3 \mu \mathrm{g} \mathrm{ml} l^{-1} \mathrm{R} \cdot \mathrm{HCl}$. Also, it is devoid of undesirable heating or extraction step involved in other methods. Therefore, the ranitidine determination not requires extensive preliminary sample treatment and expensive reagents and can be implemented easily in pharmaceutical laboratories. The method presents accuracy and precision necessary to laboratories quality control. The simplicity of the procedure and reliability of the results recommend the proposed spectrophotometric method to be used for the determination of ranitidine in pharmaceutical formulations. 


\section{REFERENCES}

1. C. Flores Perez, H. Juarez Olguin, J. Flores Perez, A. Toledo Lopez, I. Lares Asseff, C. Alvarez Garcia, J. Chromatogr. B 795, 141, (2003)

2. L.G. Hare, D.S. Mitchel, J.S. Millership, P.S. Collier, J.C. McElnay, M.D. Shields, D.J. Carson, R. Fair, J. Chromatogr. B 806, 263, (2004)

3. X.M. Kokoletsi, S. Kafkala, M. Tsiaganis, J. Pharm. Biomed. Anal. 38, $763,(2005)$

4. T.G. Nascimento, E.J. Oliveira, R.O. Macedo, J. Pharm. Biomed. Anal. 37, 777, (2005)

5. W. Li, F. Tan, K. Zhao, J. Pharm. Biomed. Anal. 41, 594, (2006)

6. A. Khedr, J. Chromatogr. B 862, 175, (2008)

7. M.K. Khadiga, M.A. Azza, M.A. Hegazy, A.F. Laila, JAOAC Int. 85, 1015, (2002)

8. M. Delgado Zamarreno, J. Hernández Méndez, A. Sánchez Pérez, Anal. Chim. Acta 176, 279, (1985)

9. V. Pfaffen, P.I. Ortiz, Ind. Eng. Chem. Res. 49, 4026, (2010)

10. S.M. Wu, H.H. Yu, L.W. Hsin, H.C. Su, S.K. Hwang, Electrophoresis 22, 2717, (2001)

11. Y.M. Issa, A.F.A. Youssef, A.A. Mutair, Il Farmaco 60, 541, (2005)

12. K. Nikolic, B. Stankovic, M. Bogavac, Pharmazie 5, 301, (1995)

13. P. Norouzi, M.R. Ganjali, P. Daneshgar, J. Pharmacol. Toxicol. Methods $\mathbf{5 5}, 289,(2007)$

14. M. Apostu, N. Bibire, G. Tântaru, Farmacia LVI, 147, (2008)

15. C. López-Erroz, P. Vinãs, N. Campillo, M. Hernández-Córdoba, Analyst 121, 1043, (1996)

16. Y.H. Tang, N.N. Wang, X.Y. Xiong, F.M. Xiong, S.J. $\underline{\text { Sun, }}$ Luminescence 22, 343, (2007)
17. S. Khalil, S.A. Ibrahim, F.I. Zedan, M.S. Abd-El-monem, Chem. Anal. (Warsaw) 50, 897, (2005)

18. European Pharmacopoeia, $6^{\text {th }}$ edition, Strasbourg, France, European Pharmacopoeia Commission, 2007; p. 2809.

19. Y. Ozsoy, B. Guvner, Acta Pharm. Turc. 29, 13, (1987)

20. S.M.H. Saad, H.M. Wagiha, M.O. Abdel Hameed, Anal. Chim. Acta 332 , 39, (1996)

21. C.S.P. Sastry, S.G. Rao, J.S.V.M.L. Rao, P.Y. Naidu, Anal. Lett. 30, 2377 , (1997)

22. M.I. Walash, F. Belal, F. Ibrahim,_M. Hefnawy,_M. Eid, JAOAC Int. 85 , $1316,(2002)$

23. S.A. Ghannam, F. Belal, JAOAC Int. 85, 1003, (2002)

24. E.M. Hassan, F. Belal, J. Pharm. Biomed. Anal. 27, 31, (2002).

25. K. Basavaiah, P. Nagegowda, Il Farmaco 59, 147, (2004)

26. A.S. Amin, I. S. Ahmed, H.A. Dessouki, E.A. Gouda, Spectrochim. Acta A 59, 695, (2003)

27. K. Basavaiah, B.C. Somashekar, J. Iran. Chem. Soc. 4, 78, (2007)

28. I.A. Darwish, S.A. Hussein, A.M. Mahmoud, A.I. Hassan, Spectrochim. Acta A 69, 33, (2008)

29. B. Narayana, K. Ashwini, D. Narayana Shetty, K. Veena, Eurasian J. Anal. Chem. 5, 63, (2010)

30. A. Sokół, J. Karpińska, R. Taleka, B. Starczewska, Acta Pol. Pharm. 68 $169,(2011)$

31. J. Rose in Advanced Physico-chemical Experiments, Pitman and Sons eds., London, 1964; pp.67-69.

32. J. Ermer, J. Pharm. Biomed. Anal. 24, 755, (2001)

33. J.N. Miller, J.C. Miller, Statistics and Chemometrics for Analytical Chemistry, Prentice Hall, England, 2005; p.256. 